\title{
What Ultrasound Operators Must Be Well Aware of in a World With Raising Burden of Non Alcoholic Fatty Liver Disease?
}

\author{
Was müssen Ultraschall-Anwender hinsichtlich der aktuell zunehmenden Krankheitslast \\ der nicht alkoholischen Fettlebererkrankung wissen?
}

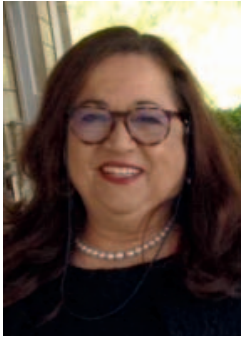

Cosima Schiavone

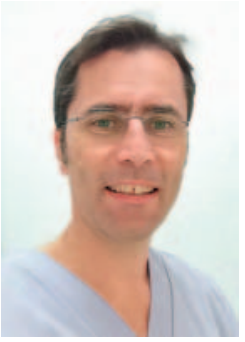

Fabio Piscaglia

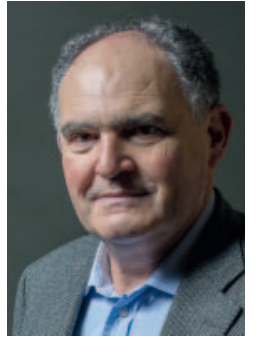

Giovanni lannetti

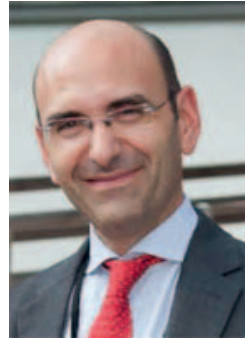

Vito Cantisani
Correspondence

Prof. Dr. Fabio Piscaglia

Dpt of Medical and Surgical Sciences DIMEC Unit of Internal

Medicine, via Albertoni 15, 40138 Bologna, Italy

fabio.piscaglia@unibo.it
Bibliography

DOI https://doi.org/10.1055/a-0808-8062

Published online: 2019

Ultraschall in Med 2019; 40: 7-10

(c) Georg Thieme Verlag KG, Stuttgart · New York

ISSN 0172-4614
Non alcoholic fatty liver disease (NAFLD) is one of the manifestations of the metabolic syndrome. The latter is mainly determined by the presence of overweight and type 2 diabetes, whose prevalence is rapidly raising in developed Countries (almost $40 \%$ in adult US Americans in 2013 - 2016) [1] in keeping with more food availability, cheap trash food, rich in fat, and soft drinks rich in sugar. The trend is even more worrisome, if one considers also the rapidly growing prevalence of children obesity. Given the magnitude of such a problem, expected to fully blow in the third decade of the third millennium, that we will be entering in less than 12 months, and the potential role of ultrasound in these patients a critical appraisal to this issue, as seen from the ultrasonographic standpoint, appears relevant.

The problem of NAFLD has been considered of minor importance so far, being fatty liver held only as a stigma of gourmets in the past, with marginal clinical consequences. However, awareness of the risks of progression of NAFLD to non-alcoholic steatohepatitis (NASH) and eventually to cirrhosis, potentially complicated by liver failure and hepatocellular carcinoma is now becoming widespread. Fortunately, only a minority of NAFLD patients will progress to NASH and cirrhosis (estimated progression to cirrhosis $<5 \%$ lifetime in NAFLD) [2, 3], but given the prevalence of overweight, diabetes and of NAFLD this leads anyhow to a huge number of patients in Europe. It is therefore crucial to identify which patients are suffering progressive significant fibrosis among NAFLD subjects in order to mandate more strict changes in lifestyle, critically choose antidiabetic therapies and possibly recommend specific fibrosis slowing drugs in the future, whenever they will become available. Unfortunately, no easy and effective tool exist today for individual fibrosis staging, but among the various tools at hand, ultrasound-based techniques appear to play a prominent role, considering also elastography and Doppler techniques [4-6].

However a widespread use of ultrasound in this field faces big challenges. In fact, despite being the most convenient instrument for the assessment of NAFLD, ultrasound also suffers significant limitations that operators must be well aware of, to avoid erroneous management of such patients.

- Conventional gray scale ultrasound is not highly sensitive for the detection of early cirrhosis, especially before clinically significant portal hypertension has developed [6]

- The presence of fatty liver, with acoustic attenuation, may prevent adequate explorability of the entire parenchyma, particularly of the deepest areas, possibly preventing the recognition of the coarse cirrhotic echotexture and the detection of deeply seated focal liver lesions. Worth to remind that hepatocellular carcinoma occurring in a background of NAFLD develops before the progression to the cirrhotic stage in half of the cases [7]. Hence if limited explorability of the liver occurs, it has to be indicated in the report.

- The accuracy in the assessment of the liver profiles, which is a key feature to detect cirrhosis, is usually improved by the use of linear transducers, but this approach may become impossible when the thickness of the subcutaneous fat makes the liver too deep. 
- Ultrasound shear wave elastography (SWE) is an extremely useful technique to suggest the presence of significant fibrosis or cirrhosis [4]. However, despite thresholds for such stages are known to be higher in NALFD than in viral chronic liver disease, precise values have not been definitively defined, differently from viral diseases [4].

- Most informations on ultrasound SWE has been produced with Transient Elastography with Fibroscan. Using such equipment it is known that the XL probe produces slightly lower values than the M probe, but the failure rate in obese subjects is much lower. Attention is to be paid to indicate the utilized probe and to judge the measurement accordingly.

- The occurence of fatty infiltration can lead to overestimation of liver stiffness, expecially when the fatty infiltration is severe (even when only graded by conventional ultrasonography), by up to $2-3 \mathrm{kPa}$ [8]. This bias might be crucial in fibrosis estimation in the intermediate stages [9]. Indeed it was shown that additional information about the severity of fatty infiltration, such as those provided by the ultrasound based Controlled Attenutation Parameter (CAP), could contribute to provide more accurate fibrosis estimation in NAFLD patients $[8,10]$. Hence future assessment of NAFLD patients should probably consider the assessment of the degree of severity of fatty infiltration.

- Very few other equipments beside Fibroscan have been assessed specifically in NAFLD patients having histology as reference standard [11]. Hence the estimation of staging by other non validated instruments is questionable. Only ruling out any significant fibrosis appears possibile, when liver stiffness is obsiously low (as a rule of thumb in the authors' view $<5 \mathrm{kPa}$ ).

- It has still to be proven if the distribution of fibrosis (and consequently the accuracy of ultrasound SWE) is homogeneous throughout the liver in NAFLD. Hence sampling in different right liver lobe areas might be recommended to better average the liver conditions.

- The failure rate of ultrasound SWE in overweight and obese subjects is reported to be higher than in normal weight subjects (on average the failure rate appears to be lower with pSWE technologies than 2 D.SWE on obese subjects, but at the price of higher dispersion of the values around the median) [11]. Quality indicator of Ultrasound SWE reliability have not been specifically developed in NAFLD and for most equipments they either do not exist at all or are provided but without any evidence compared to histological validation. Thus the ultrasound operator has little data to judge how reliable would be her/his stiffness estimations, expecially in case of fatty liver.

- The number of overweight and diabetic patients is enormous. For this reason, even a small fraction of false positive cases would translate in a significant number of unneeded additional diagnostic investigations, carrying a risk of adverse events (e. g. in case of liver biopsy) or abuse of precious healthcare resources (e. g. portal vein pressure measurement, MRI elastography, etc). Therefore a screening of patients at high risk of advanced NAFLD related chronic liver disease, requiring ultrasound and SWE investigations, by simple non-invasive scores, appears recommended as for instance using simple clinical/laboratoristic scores, such as the NAFLD Fibrosis score. Prelimin- ary data with such strategy on a very large population of NAFLD patients $(n=800)$ repeatedly submitted to non invasive tests, including ultrasound transient elastography, and to to biopsy within the STELLAR studies has been presented in November 2018 [12]. Such series, beside the data on sequential use of non invasive tests, also showed a rate of $0.7 \%$ of serious adverse events from biopsy with large needles, reinforcing the need for optimal strategies with noninvasive tests, among which ultrasound based techniques play a central role.

In conclusion ultrasound operators must pay significant attention to remain updated about the optimal and validated diagnostic work up for liver assessment in patients with metabolic syndrome and non alcoholic fatty liver disease to avoid the risk of poor patient management.

\section{Was müssen Ultraschall-Anwender hinsichtlich der aktuell zunehmenden Krankheitslast der nicht alkoholischen Fettlebererkrankung wissen?}

Die nicht alkoholische Fettlebererkrankung („non-alcoholic fatty liver disease“, NAFLD) ist eine der Manifestationen des metabolischen Syndroms. Letzteres ist hauptsächlich durch Übergewicht und Typ-2-Diabetes bedingt, dessen Prävalenz in den entwickelten Ländern rasch zunimmt (fast $40 \%$ bei erwachsenen US-Amerikanern im Zeitraum 2013 - 2016) [1], einhergehend mit der Verfügbarkeit von immer mehr Nahrungsmitteln, billigem, sehr fettreichem Fastfood, sowie stark zuckerhaltigen Softdrinks. Noch besorgniserregender ist dieser Trend angesichts der rasant zunehmenden Prävalenz von Adipositas bei Kindern. Einerseits angesichts der Größenordnung dieses Problems, das in der dritten Dekade unseres dritten Jahrtausends, die wir in weniger als 12 Monaten erreichen, voraussichtlich voll zum Tragen kommen wird, und andererseits angesichts der potenziellen Rolle des Ultraschalls bei diesen Patienten ist die kritische Beurteilung aus der sonografischen Sicht in dieser Ausgabe äußerst relevant.

Das Problem der NAFLD hatte bisher einen geringeren Stellenwert, da die Fettleber in der Vergangenheit nur als Symptom bei Feinschmeckern galt, das marginale klinische Folgen hatte. Das Bewusstsein für das Progressionsrisiko einer NAFLD zur nicht alkoholischen Steatohepatitis (NASH) und schließlich zur Leberzirrhose mit den möglichen Komplikationen Leberversagen und hepatozelluläres Karzinom ist jedoch inzwischen weit verbreitet. Glücklicherweise entwickelt nur eine Minderheit der NAFLD-Patienten NASH und Zirrhose (geschätzte Progression zur Zirrhose $<5 \%$ Lebensdauer bei NAFLD) [2, 3], aber angesichts der Prävalenz von Übergewicht, Diabetes und NAFLD führt dies dennoch zu einer beträchtlichen Anzahl an Patienten in Europa. Es ist daher wichtig zu ermitteln, bei welchen Patienten mit NAFLD eine progressive, signifikante Fibrose vorliegt, um strengere Änderungen des Lebensstils einzufordern, Antidiabetika-Therapien kritisch auszuwählen und möglicherweise zukünftig spezifische Fibroseverlangsamende Medikamente zu empfehlen, sollten diese verfügbar werden. Leider gibt es heutzutage keine einfache und 
effektive Methode für ein individuelles Fibrose-Staging, aber anscheinend nehmen unter den verschiedenen zur Verfügung stehenden Methoden die ultraschallbasierten Techniken - darunter auch Elastografie und Dopplertechiken - eine herausragende Rolle ein [4-6].

Die breite Nutzung von Ultraschall auf diesem Gebiet steht jedoch vor großen Herausforderungen. Obwohl Ultraschall die geeignetste Methode für die Beurteilung der NAFLD ist, unterliegt er auch erheblichen Einschränkungen, die den Anwendern bekannt sein müssen, um eine potenzielle Falschbehandlung solcher Patienten zu vermeiden.

- Der konventionelle Graustufen-Ultraschall ist für die Erkennung einer frühen Zirrhose nicht besonders empfindlich, insbesondere ehe sich eine klinisch signifikante portale Hypertonie entwickelt hat [6].

- Das Vorliegen einer Fettleber - mit akustischer Abschwächung - kann eine adäquate Untersuchung des gesamten Parenchyms, insbesondere der tiefsten Bereiche, verhindern, was möglicherweise dazu führt, dass die grobe zirrhotische Echotextur nicht erkannt wird und tiefsitzende fokale Leberläsionen nicht detektiert werden. Wichtig ist hierbei zu erwähnen, dass hepatozelluläre Karzinome, die im Zusammenhang mit einer NAFLD auftreten, in der Hälfte der Fälle noch vor dem Übergang zum zirrhotischen Stadium entstehen [7]. Wenn also eingeschränkte Untersuchungsbedingungen bei der Leber auftreten, muss dies im Bericht angegeben werden.

- Die Genauigkeit bei der Beurteilung der Leberprofile, die ein wesentlicher Marker bei der Diagnosestellung einer Zirrhose sind, wird normalerweise durch Einsatz von Linearschallköpfen verbessert. Dieser Ansatz ist jedoch nicht möglich, wenn durch die Dicke des Unterhautfettgewebes die Leber zu tief sitzt.

- Ultraschall-Scherwellen-Elastografie (SWE) ist eine äußerst nützliche Methode, um eine signifikante Fibrose oder Zirrhose zu erkennen [4]. Obwohl bekannt ist, dass die Grenzwerte für diese Stadien bei NALFD höher sind als bei chronisch viralen Lebererkrankungen, wurden im Gegensatz zu Viruserkrankungen keine genauen Werte festgelegt [4].

- Die meisten Informationen zur SWE-Sonografie wurden mit transienter Elastografie mittels Fibroscan erzielt. Bei Verwendung solcher Geräte ist bekannt, dass die XL-Sonde etwas niedrigere Werte als die M-Sonde erzeugt; die Ausfallrate bei adipösen Personen ist jedoch viel niedriger. Es ist darauf zu achten, dass die verwendete Sonde angegeben wird und die Messung entsprechend beurteilt wird.

- Das Auftreten einer Fettinfiltration kann zu einer Überschätzung der Lebersteifigkeit um bis zu 2 - 3 kPa führen, insbesondere bei schwerer Fettinfiltration (selbst wenn diese nur durch konventionelle Sonografie graduiert wurde) [8]. Dieser systematische Fehler könnte für die Einschätzung der Fibrose in den intermediären Stadien von entscheidender Bedeutung sein [9]. Tatsächlich konnte gezeigt werden, dass zusätzliche Informationen über den Schweregrad der Fettinfiltration, wie sie der ultraschallbasierte „Controlled attenuation parameter“ (CAP) liefert, zu einer genaueren Fibrosebeurteilung bei NAFLD-Patienten beitragen können $[8,10]$. Daher sollte die zukünftige Beurteilung von NAFLD-Patienten möglichst die Bewertung des Schweregrades der Fettinfiltration berücksichtigen.
- Neben Fibroscan wurden nur wenige andere Geräte speziell bei NAFLD-Patienten mit Histologie als Referenzstandard untersucht [11]. Daher ist eine Staging-Beurteilung durch andere nicht validierte Methoden fragwürdig. Der Ausschluss einer signifikanten Fibrose erscheint nur dann möglich, wenn die Lebersteifigkeit deutlich niedrig ist (Faustregel nach Ansicht der Autoren < $5 \mathrm{kPa}$ ).

- Es muss noch geprüft werden, ob bei NAFLD die Verteilung der Fibrose (und folglich die Genauigkeit des Ultraschall-SWE) in der gesamten Leber homogen ist. Daher sollte die Entnahme von Proben aus verschiedenen Bereichen des rechten Leberlappens empfohlen werden, um den Leberzustand im Durchschnitt zu ermitteln.

- Die Ausfallrate von Ultraschall-SWE bei übergewichtigen und adipösen Personen ist Berichten zufolge höher als bei normalgewichtigen Personen (im Durchschnitt scheint bei adipösen Personen die Ausfallrate bei pSWE-Technologien niedriger zu sein als bei 2D-SWE, jedoch zu Lasten einer höheren Streuung der Werte um den Median) [11]. Ein Qualitätsindikator für die Genauigkeit der Ultraschall-SWE bei NAFLD wurde nicht speziell entwickelt und ist für die meisten Geräte entweder überhaupt nicht vorhanden oder, falls doch vorhanden, es fehlt die Evidenz im Vergleich zur histologischen Bewertung. Dem Ultraschall-Anwender liegen somit nur wenige Daten vor, um zu beurteilen, wie zuverlässig seine Steifigkeitsschätzungen sind, insbesondere bei Fettleber.

- Die Zahl der Patienten mit Übergewicht und Diabetes ist enorm. Aus diesem Grund würde selbst ein geringer Anteil an falsch positiven Fällen zu einer erheblichen Anzahl unnötiger zusätzlicher diagnostischer Untersuchungen führen, die das Risiko von Nebenwirkungen (z. B. bei Leberbiopsie) oder die unsachgemäße Nutzung wertvoller Ressourcen im Gesundheitswesen (z. B. Messung des Pfortaderdrucks, MRT-Elastografie usw.) mit sich bringen. Daher ist das Screening von Patienten mit hohem Risiko für eine fortgeschrittene NAFLDbedingte chronische Lebererkrankung, die Ultraschall- und SWE-Untersuchungen benötigen, mittels einfacher, nichtinvasiver Scores, wie zum Beispiel dem unkomplizierten klinisch/ labordiagnostischen NAFLD-Fibrose-Score, empfehlenswert. Vorläufige Daten zu einer solchen Vorgehensweise bei einem sehr großen Kollektiv von NAFLD-Patienten $(n=800)$, die sich wiederholt nichtinvasiven Tests einschließlich transienter Ultraschall-Elastografie und Biopsie im Rahmen der STELLAR-Studien unterzogen, wurden im November 2018 vorgelegt [12]. Diese Untersuchung zeigte neben den Daten zum sequenziellen Einsatz nichtinvasiver Tests auch eine Rate von $0,7 \%$ in Bezug auf schwerwiegende Nebenwirkungen bei Biopsie mit großen Nadeln. Dies spricht für die Notwendigkeit eines optimalen nichtinvasiven Vorgehens, bei dem ultraschallbasierte Techniken eine zentrale Rolle spielen.

Zusammenfassend ist zu sagen, dass die Ultraschallanwender stets die aktuellen Entwicklungen in Bezug auf das optimale und validierte diagnostische Vorgehen bei der Leberuntersuchung bei Patienten mit metabolischem Syndrom und nicht alkoholischer Fettlebererkrankung im Auge behalten sollten, um nicht leichtfertig ein schlechtes Patientenmanagement zu riskieren. 


\section{References}

[1] Hales CM, Fryar CD, Carroll MD et al. Differences in Obesity Prevalence by Demographic Characteristics and Urbanization Level Among Adults in the United States, 2013-2016. JAMA 2018; 319: 2419-2429

[2] European Association for the Study of the Liver (EASL); European Association for the Study of Diabetes (EASD); European Association for the Study of Obesity (EASO). EASL-EASD-EASO Clinical Practice Guidelines for the management of non-alcoholic fatty liver disease. J Hepatol 2016; 64: $1388-1402$

[3] Italian Association for the Study of the Liver (AISF). AISF position paper on nonalcoholic fatty liver disease (NAFLD): Updates and future directions. Dig Liver Dis 2017; 49: 471-483

[4] Dietrich CF, Bamber J, Berzigotti A et al. EFSUMB Guidelines and Recommendations on the Clinical Use of Liver Ultrasound Elastography, Update 2017. Ultraschall in Med 2017; 38: 377-394

[5] Tana C, Schiavone C, Ticinesi A et al. Hepatic artery resistive index as surrogate marker for fibrosis progression in NAFLD patients: A clinical perspective. Int J Immunopathol Pharmacol 2018; 32: 2058738418781373

[6] Tana C, Tana M, Rossi S et al. Hepatic artery resistive index (HARI) and non-alcoholic fatty liver disease (NAFLD) fibrosis score in NAFLD patients: cut-off suggestive of non-alcoholic steatohepatitis (NASH) evolution. J Ultrasound 2016; 19: 183-189
[7] Piscaglia F, Svegliati-Baroni G, Barchetti A, HCC-NAFLD Italian Study Group et al. Clinical patterns of hepatocellular carcinoma in nonalcoholic fatty liver disease: A multicenter prospective study. Hepatology 2016; 63: $827-838$

[8] Petta S, Maida M, Macaluso FS et al. The severity of steatosis influences liver stiffness measurement in patients with nonalcoholic fatty liver disease. Hepatology 2015; 62: 1101-1110

[9] Piscaglia F, Salvatore V, Mulazzani L et al. Ultrasound Shear Wave Elastography for Liver Disease. A Critical Appraisal of the Many Actors on the Stage. Ultraschall in Med 2016; 37: 1-5

[10] Petta S, Wong VW, Cammà C et al. Improved noninvasive prediction of liver fibrosis by liver stiffness measurement in patients with nonalcoholic fatty liver disease accounting for controlled attenuation parameter values. Hepatology 2017; 65: 1145-1155

[11] Cassinotto C, Boursier J, de Lédinghen V et al. Liver stiffness in nonalcoholic fatty liver disease: A comparison of supersonic shear imaging, FibroScan, and ARFI with liver biopsy. Hepatology 2016; 63: 1817-1827

[12] Younossi ZM, Lawitz E], Akhouri N et al. Algorithms using noninvasive tests can accurately identify patients with advanced fibrosis due to NASH: data from the STELLAR clinical trials. Abstract presented at AASLD: The Liver Meeting 2018. Hepatology 2018. suppl1: LB-10 